\title{
Paradigm Of Legal Thought: Legal Prophetic Perspective
}

\author{
Fitrah Hamdani \\ Universitas Muhammadiyah Surakarta \\ jiwanta90@gmail.com
}

DOI: $10.23917 /$ jtI.v2i1.11328

Submission
Track:
Received:
30 June 2020
Final Revision:
04 July 2020
Available online:
31 July 2020
Corresponding
Author:
Fitrah Hamdani
jiwanta90@gmail.com

\begin{abstract}
Objective: This article aims to discuss 'criticism of legal prophetic paradigm against legal positivism paradigm
\end{abstract}

Methodology: This research conducted a normative method used by legal positivists. This research is based on a philosophical approach as it is intended to explore the basic assumptions of the legal prophetic paradigm on the lack of the basic assumptions of the legal positivism paradigm.

Findings: This paper will discuss the 'criticism of legal prophetic paradigm against legal positivism paradigm' using a philosophical approach as it is intended to explore the basic assumptions of the epistemology basis of the school of thought in legal science through comparison between the school of thoughts in legal science. The legal prophetic paradigm places moral as the main basis as its basic assumption. The verses of Allah and the Hadith of the Prophet regarding justice are the ontological basis of the Paradigm.

Application of the Study: The object of legal science is human relations contained within (governed by) legal norms. Law science attempts to understand its object in a "legal" manner, which is from the legal perspective. Understanding something legally means understanding it as law, that is, as legal norms or as the content of legal norms or understanding something as determined by legal norms.

Novelty/Originality: The prophetic paradigm can be approached through a Religion Science-based approach. The importance of this approach/religion science in understanding phenomenological law is none other but the occurrence of void or the broken links due to legal positivism thinking that is unable to play a functional role in presenting comprehensive legal justice.

Keywords: Legal Positivism Paradigm, Legal Prophetic Paradigm, Basic Assumptions

\section{INTRODUCTION}

Kuhn's paradigm conception - as interpreted by Newton-Smith includes a) Generic symbolic generalizations, which are assumptions or main theoretical assumptions that are 
collectively believed and are unquestionable, b) Models, which are analogies or parables about the phenomena under the study and agreed upon as heuristic devices for conducting research, c) Values. Kuhn affirms that the scientific community fundamentally adheres to certain values in its scientific activities, d) Metaphysical principles, namely assumptions that are not required to be tested but determine the direction of research, and e) Concrete problems -Kuhn called it "Exemplar" - are problems learned and ways to solve them. Those aspects are considered important by Kuhn since the debate about which paradigms should be followed also involves the question of which problems are more high-prioritized to solve. ${ }^{1}$

The process of a paradigm shift in various fields of science also has an impact on the development of legal studies. The law clearly has a paradigm, which is a basic perspective. ${ }^{2}$ The existence of the legal paradigm simultaneously brings the consequence of the need to observe the law as an institution that expresses that paradigm. The discussion of law will easily be misunderstood when it ignores the legal paradigm. By finding the paradigm behind the law, an understanding of the law will come to light. If, for instance, the value is a paradigm, the law will also appear as an institution that expresses the value. There are various legal paradigms, and as a result, the law also expresses various things according to its paradigm or basic perspective.

The basic perspective or can be referred to as basic assumption is a view about a thing, object, science, the purpose of discipline, and so forth, whose truth is unquestionable or the truth has been fully accepted. This view is the commencement or basis of efforts to understand and answer a problem because these views are considered true or believed to be true. The assumptions can arise from: (a) philosophical and reflective thinking; (b) sophisticated empirical studies; and (c) careful observations. As a matter created through philosophical and reflective thinking, it is very closely related to the ideology of science, ethics, religion, space, and time that affects its subjectivity in understanding reality, making decisions, and defining the phenomena it encounters. ${ }^{3}$ As shown in Nur Ichwan's criticism of Nasr Hamid Abu Zayd's hermeneutic theory, which states that subjective awareness and ideological tendencies are

\footnotetext{
${ }^{1}$ Heddy Shri Ahimsa-Putra, Paradigma dan Revolusi Ilmu dalam Antropologi Budaya, Sketsa Beberapa Episode, Speech in Professor Inauguration in Faculty of Cultural Science Gadjah Mada University, Delivered in Open Meeting of Professor Gajah Mada University, Yogyakarta, on November10 ${ }^{\text {th }}$, 2008. p. 5.

2 Satjipto Rahardjo. Sosiologi Hukum Perkembangan Metode dan Pilihan Masalah. Surakarta: Muhammadiyah University Press, 2002 p. 59.

${ }^{3}$ Heddy Shri Ahimsa Putra, Paradigma Profetik; Mungkinkah? Perlukah?, Paper delivered in "Sarasehan Profetik 2011”, presented by Graduates School of UGM, in Yogyakarta, February 10 ${ }^{\text {th }}, 2011$ pp. 33-34.
} 
essential in composing epistemological assumptions. Therefore it is unnecessary to be removed. At this level, awareness has operated in a real stage, which is the epistemological stage. $^{4}$

Epistemological assumptions are assumptions about the grounds of knowledge - about how individuals begin to understand the world and explain it as knowledge to others, whether about the form, the assessment of right and wrong, or the nature of knowledge that can be obtained. These assumptions are used to answer the possibility of individuals in identifying and delivering knowledge as an objective reality (positivism) that attempts to explain, predict what will happen to the social by finding habits and causal relationships between the main elements, or the individual technique one does to obtain more subjective reality (antipositivism). Therefore, knowledge is something that must be experienced personally and opposes the search for laws or basic habits in social matters which argue that the social world can only be understood from the individual perspective that is directly involved in the activities under study. ${ }^{5}$

At a methodological level, positivism emphasizes factual and well-known human experience, which is the main foundation of truth. In other words, all elements in the form of factual explanations must be disregarded. Automatically, the position of the senses is very important in gaining knowledge, yet it must be refined with tools and strengthened by experiments. If any mistake is found in the senses, it can be mended through experiments because experiments will provide clear measurements.

The basic assumption of positivism about reality is singular in the sense that natural phenomena and human behavior are bound by the rule of law. The focus of positivism studies is causality. ${ }^{6}$ In regard to this notion, the positivism stream proposes two ways to find out; ${ }^{7}$ First, direct verification through empirical data; Second, rational discoveries.

\footnotetext{
${ }^{4}$ Moch Nur Icham, Meretas Kesarjaan Kritis Al-Quran: Teori Hermeneutika Nas Abu Zayd, Teraju, Jakarta, 2003, p. 159.

${ }^{5}$ Anis Chariri, "Landasan Filsafat dan Metode Penelitian Kualitatif", Paper delivered in Workshop of Quantitative and Qualitative Research Methodology, Laboratory of Accounting Development (Laboratorium Pengembangan Akuntansi/LPA), Faculty of Economy Diponegoro University, Semarang, July $31^{\text {st }}$-August $1^{\text {st }}$, 2009, pp. 1-4 in Saepul Rochman, Paradigma Profetik Dalam Ilmu Hukum (Kritik Terhadap Asumsi-Asumsi Dasar Ilmu Hukum Non-sistematik), Thesis, Faculty of Law Universitas Muhammadiyah Surakarta, Surakarta, November 2014, pp. 42-43.

6 Indriyani Purwaningsih, "Perspektif Positivisme \& Post-Positivisme", http://catatananakfikom.blogspot.com/2012/03/perspektif-positivisme-post-positivisme.html, accessed on 22-4-12, in Kaila Azzahra, Aliran Filsafat Positivisme, dalam http://kaylaazzrt.blogspot.com/2013/01/tugas-makalah-konsep-pikiraliran_1401.html, accessed on June $20^{\text {th }}, 201023.402014$

${ }^{\overline{7}}$ Ibid.
} 
Hence, the truth adhered by positivism in finding the truth is the correspondence theory. Correspondence theory expresses that a statement is valid if empirical facts are supporting the statement, in other words, a statement is considered to be true if the material contained therein corresponds with the factual object appointed by the statement. ${ }^{8}$

In for around 200 years of the science of law, countries in the world use the concept of modern law. Practically, the law confronts the questions, which are specialist, technological, but not moral questions. Such a situation is strongly visible in the law as a profession. Professionals are individuals who are experts in legal matters but are not the people to ask about moral issues. The excess of law in America which has become a business invites people to comment that the nature of the knighthoods, professional, and helping people in need has faded. ${ }^{9}$

The birth of legal positivism was an influence of positivism philosophy in the $19^{\text {th }}$ century. This philosophy is rooted in what is already known, factual, and positive. Elaborations and problems beyond what exists as facts and realities are set aside. ${ }^{10}$ What we believe as positive is everything visible, every phenomenon is ontological basis of legal positivism. Based on the assumption of using logic and scientific methods into the social sciences, therefore, social sciences (including legal science) in its development arise empirical, rigid, written, and methodological characteristics.

The birth of legal positivism began as a critique of natural law, to put precisely, an evolution from an understandable tendency, which is theistic natural law, positivistic natural law because it tends merely to the knowledge of aqliah (logic) or the law promulgated by the king as a divine representative for the law is theistic but tends to be positivistic and creates legal positivism which separates natural law and legal positivism. It is in accordance with Comte's opinion that past history can only be judged by the criteria of scientific knowledge that is the only truth to which all forms of knowledge are referred to, and Hegel also desired to view positive philosophy as a historical objective. Thus he was not ready to adhere the postpositivism stage. ${ }^{11}$

\footnotetext{
${ }^{8}$ Ibid.

9 Asikin Zainal, Mazhab Positivisme Hukum, dalam http://asikinzainal.blogspot.com/2012/10/mashabpositifisme-hukum.html, accessed on December $27^{\text {th }}, 201323.25$

${ }^{10}$ Ibid.

${ }^{11}$ F. Budi Hardiman, Filsafat Modern Dari Machiavelli Sampai Nietszche, Jakarta : PT. Gramedia Pustaka Utama, 2007. p. 208.
} 
According to Shidarta, the logical pattern of legal positivism is one-way top-down. The relationship between norms, facts, and legal consequences tends to be filled with the partiality of the legal norms as normative premises that are considered to have fulfilled and validated the principles of exclusion, the principle of sub-assumptions, the principle of derogation, and the principle of non-contradiction. The norms applied are considered flawless from errors. Thus, the reality as data and objects must follow the norms that have been outlined as the legal consequences have also been predetermined. ${ }^{12}$

On the other side, the formulation of Legal Prophetic Studies in Legal Science based on paradigmatic, assumptions, principles, theories, methodologies, and structure of norms contained therein, is built on the basis of Islamic epistemology based on the Qur'an and Hadith. Through the process of transformation and objectification of Islamic teachings that originate from the Qur'an and Hadith, basic assumptions will be created which then descend into theories, doctrines, principles, rules, and legal norms that apply in society as per each context. ${ }^{13}$

According to Heddy, to insert the "sacred" element into Legal Science is by repositioning material objects of Prophetic Science. The assumption that needs to be raised in the presence of the universe and human life is an existing reality. Nonetheless, this reality does not arise by itself (there is the creator). Therefore, human beings must treat reality properly. The improper treatment of reality must be based on reasons that can be justified ethically and aesthetically, which are regulated in the Qur'an and Hadith. Also, repositioning the objective reality as God's creation, according to Kuntowijoyo is called a transcendence process, or in Kunto's term, it is a form of tukminuna billah (truly believe in Allah). ${ }^{14}$

\section{PROBLEM FORMULATION}

Based on the explanation of the background, to be operational, problem formulation of this study will discuss; First, the weakness of the basic assumptions of the legal positivism paradigm, and Second, criticism on the basic assumptions of the legal prophetic paradigm on legal positivism.

12 Shidarta, Bandung, Karakteristik Penalaran Hukum Dalam Konteks Keindonesiaan, Bandung: CV. Utomo, 2006. p. 250

${ }^{13}$ M. Syamsudin (Penyunting: M. Koesnoe, Heddy Shri Ahimsa Putra dkk), Ilmu Hukum Profetik (Gagasan Awal, Landasan Kefilsafatan dan Kemungkinan Pengembangannya di Era Postmoderen), Yogyakarta: Pusat Study Hukum FH-UII, 2013. p. 101

${ }^{14}$ Kuntowijoyo. Islam Sebagai Ilm; Epistemologi, Metodologi dan Etika, Jakarta: Teraju PT. Mizan Publika, 2004.p. 107, Dalam M. Syamsudin (Editor: M. Koesnoe, Heddy Shri Ahimsa Putra, et al.), Ilmu Hukum Profetik...2013. Ibid. p. 102 


\section{METHOD}

This research conducted a normative method used by legal positivists. A normative method is a method in analyzing laws since the object of discussion is the norm or principle. To test the validity, a non-descriptive theory of truth ${ }^{15}$ may be utilized because this theory emphasizes the use of the word 'true' to express agreement or accept a proposition and 'false' as a rejection to a proposition. A true statement is not a statement that reveals reality, yet that statement creates reality, as expressed in that statement.

The basic assumptions underlying the assessment of the knowledge, in an epistemological perspective, show that knowledge is not only related to truth, validity, and reliability, but also to the concepts of belief, trust, and proof. In a more specific construction, the basic assumption is the interrelation of knowledge and belief. In basic assumption, there is an epistemology of the paradigm of a particular legal thought.

This research is based on a philosophical approach because it is intended to explore the basic assumptions of the legal prophetic paradigm on the weaknesses of the basic assumptions of the legal positivism paradigm stream.

\section{DISCUSSION}

\section{Basic Assumptions of Legal Positivism Paradigm}

The school of thought of positivism considers that natural science is the only valid source of knowledge and rejects metaphysical activities. There is no speculation, all based on empirical data. This school of thought declines the existence of theoretical speculation as a means of gaining knowledge (as put forward by idealists, especially Classical German idealism).

Positivism has reduced the abundance of human experience and imagination in knowledge to empirical facts. The value-free principle of positivism has produced the scientific world to become "heartless robots". Positivism results in the unprosperous universe of infinite inner wealth; the scientific universe has become desacralization. The positivism method

${ }^{15}$ Non-descriptive theory of truth was developed by adherents of functionalism. A statement is considered true, depending on the role and function of the statement itself. Knowledge will have a truth value as long as the statement has a very practical function in daily life. And this theory was initiated by Victor Reisskop and Isaac Newton. In Wikipedia.org, the Correspondence theory of truth Teori in http://perilakuorganisasi.com/teorikebenaran-ilmiah.html, Accessed on May 26 ${ }^{\text {th }}, 2020,23.40$ 
assumes that natural objects move in a deterministic-mechanical way. The consequence of these assumptions is that human beings move solely based on stimulus and response, stimulation, and reaction.

The philosophy of positivism in the $19^{\text {th }}$ century influenced the legal positivism stream. This philosophy is rooted in what is known, factual, and positive. Elaborations and problems beyond what exists as facts and realities are set aside. ${ }^{16}$ What we believe as positive is everything visible, every phenomenon is ontological basis of legal positivism. Based on the assumption of using logic and scientific methods into the social sciences, therefore, social sciences (including legal science) in its development arise empirical, rigid, written, and methodological characteristics.

Legal positivism has 2 (two) forms, which consists of juridical positivism and sociological positivism: ${ }^{17}$

a) Juridical Positivism

In the perspective of juridical positivism, the law is perceived as an individual phenomenon that needs to be processed scientifically. The aim of juridical positivism is the formation of rational structures of applicable juridical systems. In practice, this concept descends a theory that the formation of law is professional in nature, which law is the creation of jurists by having principles: ${ }^{18}$ (1) Law is equal to the constitution. It is based on the idea that law appears related to the State so that the correct law is the law applied in the State; (2) There is no absolute relationship between law and morals, or law is a mere creation of jurists, and (3) Law is a closed logical system. To interpret the law does not need the guidance of social, political, and moral norms but rather be inferred from the constitution. The figures are R. von Jhering and John Austin (analytical jurisprudence).

b) Sociological Positivism

In the perspective of sociological positivism, ${ }^{19}$ law is perceived as part of people's lives. Thus, the law is open to people's lives. This open nature, according to sociological

16 Ibid.

17 Abdul Ghofur Anshori, Filsafat Hukum, Sejarah, Aliran dan Pemaknaan, Yogyakarta: Gajah Mada University Press, 2006. pp. 92-93

18 Ibid.

${ }^{19}$ The figure of sociological positivism is Auguste Comte (1789-1857) who created a new science, sociology. In Ibid. Abdul Ghofur Anshori, Gajah Mada University Press, 2006. pp. 92-93 
positivism, must be investigated through scientific methods. In modern legal theory, positivism has gained a general understanding. Legal positivism has manifested itself in analytic jurisprudence, called Analytical Positivism. ${ }^{20}$

In principle, the separation of existing law or what is (das Sein) and the law that should exist or what ought to (das solen) is a fundamental philosophical assumption of legal positivism. By putting aside the values underlying the legal system that are essentially irrelevant to analytical legal science, analytical positivism devotes its attention to the composition of a "positive" legal system. ${ }^{21}$ This triggers positivist groups to describe specifically the legal order of the modern state, from Austin's "sovereign order" into Hans Kelsen's hierarchy regarding norms taken from hypothetical basic norms (object of study).

The source of truth of positivism is God's law and human will and mind because scientists of this stream do not neglect the position of God besides considering human ratio. ${ }^{22}$ The normative method is the method used by legal positivists. A normative method is a method in analyzing laws since the object of discussion is the norm or principle. To test the validity, a non-descriptive theory of truth ${ }^{23}$ may be utilized because this theory emphasizes the use of the word 'true' to express agreement or accept a proposition and 'false' as a rejection to a proposition. A true statement is not a statement that reveals reality, yet that statement creates reality, as expressed in that statement.

Time travel leads to the development of scientific traditions that open to new horizons in the history of mankind, which were initially invisible in traditional ways of understanding as a consequence of the existence of positive law. Positive law teaches that it governs and applies on juridical norms established by the authorities in which there is a tendency to separate

20 Analytical Positivism starts from a certain legal order, from which certain fundamental concepts, understandings, and differences are drawn using a fully inductive method, then compares to the certain fundamental differences, concepts, and thoughts from another legal order to ensure the same number of elements (Bodenheimer, 1967: 93). In this way, Analytical Positivism means completing legal science with the anatomy of a legal system, the principle of separating existing law (das sein) from the law that should exist (das solen) (Friedmann, 1990: 257), In Ibid. Abdul Ghofur Anshori, Gajah Mada University Press, 2006. p. 93

${ }^{21}$ Friedmann, W. 1990. Teori dan Filsafat Hukum. Jakarta: Rajawali, Hal. 257 in Franssisca Yuliana, Filosofi Ilmu Hukum in http://siscayulai.blogspot.com/2010/09/filosofi-ilmu-hukum.html, accessed on May $21^{\text {st }}$, 2020, 1.35

22 Franssisca Yuliana, Filosofi Ilmu Hukum In http://siscayulai.blogspot.com/2010/09/filosofi-ilmuhukum.html, accessed on May 21 ${ }^{\text {st }}, 2020,1.35$

${ }^{23}$ Non-descriptive theory of truth was developed by adherents of functionalism. A statement is considered true, depending on the role and function of the statement itself. Knowledge will have a truth value as long as the statement has a very practical function in daily life. And this theory was initiated by Victor Reisskop and Isaac Newton. In Wikipedia.org, the Correspondence theory of truth Teori in http://perilakuorganisasi.com/teorikebenaran-ilmiah.html, Accessed on May 21 ${ }^{\text {st }}, 2020,23.40$ 
wisdom from morality and identify justice with legality based on juridical norms established by state authorities in which there is a tendency to separate wisdom from ethics and identify justice with legality based on rules set by the authorities in a state.

The epistemological assumptions of the School of Thought of Legal Positivism include categories; ${ }^{24}$ (a) there is constitutive cognition, (b) norm is an independent and autonomous meaningful object of cognition, and (c) reconstructed legal norms are formed from relations between material facts that are non-causal and non-metaphysical (imputation).

\section{Criticism of Legal Prophetic Paradigm on Legal Positivism}

According to Kuntowijoyo, following Fazlur Rahman and Armahedi Mazhar, Islamic epistemology is Relational epistemology or "integralistic way of thinking," which corresponds to tauhid (monotheism) terminology. This paradigm is also known in the concept of tauhid by Muhammad Iqbal and Murtadha Muthahari, which means Islam as a universal religion in terms of space, and eternal in terms of time in specific daily reality, there is an endless continuum between the oneness of God and reality. ${ }^{25}$

Islam as a rational religion/demystification, ${ }^{26}$ as an epistemological exploration effort to reconnect Islam and reality. In Kuntowijoyo's perspective, Islam must always build dialectical interaction between reality, actuality, and life. If religion is a collection of textual revelations, then the text has lost its context. Therefore, religion is not included to build reality simultaneously. Thus, demystification is intended as an intellectual movement to reconnect texts with context, to enable correspondence between the two elements. Following Islamic demystification or Islamic scientific, Muslims will understand the environment better, both the

\footnotetext{
${ }^{24}$ Kelik Wardiono, PARADIGMA PROFETIK (Pembahasan Basis Epistemiligi Ilmu Hukum di Indonesia), Paper delivered in Seminar of Dissertation Research Result Doctoral Program Surakarta: Law Science faculty of Law Graduate School of Universitas Muhammadiyah Surakarta, on September $13^{\text {th }}, 2014$. p. 14

${ }^{25}$ The term epistemology comes from Greek which means the theory of knowledge, is the science that asks how people know and understand a reality so that people can act wisely. What are the sources of knowledge, how are they used, and how human knowledge about reality is measured. The source of knowledge for Muslims is God manifested in the empirical world in the form of the Qur'an and the Sunnah. Kuntowijoyo, Identitas Politik Umat Islam, Bandung: Mizan, 1997. pp. 1-2.

${ }^{26}$ Demystification is an effort to eliminate the mystical elements (in the gap with reality) metaphysical, social mysticism, ethical mysticism, reasoning mysticism, and reality mysticism. Metaphysical mysticism is the loss (of mortal) of a person in God called Mysticism or Sufism, whether substantial mysticism or attribute mysticism, united in the meaning of matter or the sense of will, character, and morals. Social mysticism is the loss of an individual in a larger unit, organization, sect, or community. Ethical mysticism is the loss of one's power to face his destiny and surrender to destiny (fatalism). Reasoning mysticism is the loss of reason for someone because of the events around that out of sense. Reality mysticism is the loss of religion's relationship with reality as a context. In Kuntowijoyo, Islam sebagai Ilmu: Epistemologi, Metodologi dan Etika, Jakarta: Teraju PT. Mizan Publika, 2004, Op.Cit . pp. 10, 53 dan 62.
} 
physical environment and social environment, symbolic environment, and historical environment. There are two typologies in the Islamic Scientific Methodology or Islamic demystification, namely integration and objectification. ${ }^{27}$

Objectification is needed to connect the text to its context. There is a difference between objectivation and objectification. The objectivation comes from the English objectification, the noun is formed from the verb objectify, which means not to be biased or objectively. Objectification comes from the word objectify, while objectivation comes from the word objectivate. In Webster's New Twentieth Century Dictionary, the word objectification is equal to objectivation, and both have the same meaning. ${ }^{28}$

Kuntowijoyo attempted to give a different understanding of the meaning of "objectivation" and "objectification". Objectivation originates from the word object, so objectivation perceives things as objects. For instance, the sentence, "technological society tends to objectify human beings," as the replacement of objectivation in that the sentence, it is now more common to use the word dehumanization or creating human beings as machines. Thus, Islamic scientific does not use objectivation but objectification. The word objectification comes from the word objective, which means to make something becomes objective (the act of objectifying). Something is objective if its existence does not depend on the subject's mind but independent. Objectification is the translation of internal values into objective categories, objectification is the realization of internal beliefs. An action is deemed objective if it is done by non-Muslims. It is no longer considered religiously nuanced, but something natural, though Muslims still consider it as an act related to religion. Kuntowijoyo expressess: ${ }^{29}$

"Objectification is a rational act of value (wertrational) which is manifested into a rational act so that outsiders still can enjoy without having to agree on original values. For instance, God's warning to Muslims as believers if they neglect the economic life of the poor can be objectified with IDT (Inpres Desa Tertinggal). National solidarity is the objectification of the teachings on ukhuwah (brotherhood). "

The objectification area will protect from secularization and domination because the formation of the procedure area is agreed collectively by citizens. Certain categories have

${ }^{27}$ Kuntowijoyo, Islam sebagai Ilmu; : Epistemologi, Metodologi dan Etika, Jakarta: Teraju PT. Mizan Publika, 2004, Ibid. pp. 10, 53, and 62.

${ }^{28}$ Webster's New Twentieth Century Dictionary, $2^{\text {nd }}$ edition, United State of America: William Collin Publishers, Inc, 1979, p. 207.

${ }^{29}$ Kuntowijoyo. Identitas Politik Umat Islam..., Bandung: Mizan, 1997. pp. 68-69 
become objects or objective categories, such as the state, adopting a system of government from Greece, bureaucracy from Persia, and mathematics from India. There is no religious obligation that states that Muslims must study in Mecca or Medina. The religious obligation is to learn while the appointed place is not determined by religion or determined based on objective criteria. Muslims are also required to behave objectively, as well as to be fair regardless of discrimination, relatives, status, class, or group. For Islam to be truly perceived as a grace religion for the universe (Qs. Al-Anbiya (21): 107; Al-Maidah (5): 8), regardless of religion, skin color, culture, etc., Islamic objectification is needed. ${ }^{30}$ Objectification is a way to transform normative values into a theoretical system. It is obvious that there is always an objective side of Islamic values in a whole and by transforming subjective Islamic values into objective categories, one will be able to actualize Islam empirically and be ready to face various forms of structural challenges from the development of industrial society. ${ }^{31}$

Given this notion, Kuntowijoyo put forward his views on the Islamic Paradigm (Grand Theory of the Quran), this paradigm is intended as mode of thought, mode of inquiry, which then produces a mode of knowing. He states: ${ }^{32}$

"In this sense, the Qur'an paradigm is a construction of knowledge that enables us to understand reality as the Qur'an understands it. The construction of knowledge is built by the Qur'an with the initial aim that we have "wisdom", which behavior can be formed according to the normative values of the Qur'an, whether at the moral level and the social level. But apparently, this knowledge construction also allows us to formulate a grand design of the Islamic system, including, in this case, the scientific system. Hence, besides giving axiological depiction, the Qur'an paradigm can also function to provide epistemological insight. "

The prophetic paradigm can be approached through a Religion Science-based approach. ${ }^{33}$ The importance of this approach/religion science in understanding

${ }^{30}$ Kuntowijoyo, Islam Sebagai Ilmu: Epistemologi, Metodologi dan Etika, Jakarta: Teraju PT. Mizan Publika, 2004. pp. 68 and 76. In Saepul Rochman. Thesis, Paradigma Profetik Dalam Ilmu Hukum (Kritik Terhadap Asumsi-Asumsi Dasar Ilmu Hukum Non-sistematik), Surakarta: Faculty of Law Universitas Muhammadiyah Surakarta, on November 2014. p. 441

${ }^{31}$ Kuntowijoyo, Paradigma Islam Interpretasi Untuk Aksi, Bandung: Mizan, 1998. p. 70.

${ }^{32}$ Kuntowijoyo, Islam Sebagai Ilmu, ...2004, Op. Cit. p. 12

${ }^{33}$ Religion Science is an idea about the importance of the position of religious teachings in the development of legal science. In Jawahir Thontowi, Pegembangan Ilmu Hukum Berbasis Religion Science (Dekonstruksi Flafat Pemikiran Hukum Positivistik), Paper delivered in Open Lecture in Graduate School Faculty of Law, Universitas Brawijaya Malang, Malang: August 13 ${ }^{\text {th }}$, 2011. In M. Syamsudin (Penyunting: M. Koesnoe, Heddy Shri Ahimsa 
phenomenological law is none other than due to the occurrence of void or missing links due to legal positivism thinking that is unable to play a functional role in presenting comprehensive legal justice.

In prophetic law, things to be considered is what the basis of material objects is and what distinguishes them from the law in general. To answer this, the question is, what is the essence of the law itself? In law, generally many basic assumptions are followed by legal scientists to explain what the nature of law is.

According to Soetandyo, there are at least 5 (five) basic assumptions that form different legal concepts. First, the law is conceptualized as a moral principle or justice principle which is universal and becomes an inherent part of the natural legal system, or even sometimes, it is also believed to be part of supernatural principles. Second, the law is conceptualized as positive principles that are generally accepted (in abstracto) at a certain time in a certain region and are emerged as explicit products by certain sources of legitimate political power, or commonly known as State law. Third, the law is conceptualized as judgment decided by the judge (in concreto) in the judicial process as part of the judge's efforts in resolving disputes that are possible as a precedent for resolving subsequent cases. Fourth, the law is conceptualized as a real and functional social institution in the social system, whether in the processes of resolving disputes settlement, as well as in directing processes of shaping behavior patterns. Fifth, law is conceptualized as symbolic meanings as manifested in social interaction. ${ }^{34}$

Based on the legal concept revealed by Soetandyo, the first basic assumption (law as moral principle) is in line with the basic assumptions of Prophetic Law. Yet, the concept still needs to be "filled" more clearly related to the characteristics of the prophetic paradigm, which can be demonstrated by the basic assumption, "that the law is essentially God's will about something which source is contained in the Qur'an and Hadith ". Thus, the verses of Allah and the Hadith of the Prophet regarding justice are the ontological basis of the Legal Prophetic Paradigm Studies. ${ }^{35}$

Putra dkk), Ilmu Hukum Profetik (Gagasan Awal, Landasan Kefilsafatan dan Kemungkinan Pengembangannya di Era Postmoderen), Yogyakarta: Pusat Study Hukum FH-UII, 2013.p. 239

${ }^{34}$ Soetandyo Wignjosoebroto, Hukum Paradigma, Metode dan Dinamika Masalahnya, Jakarta: Huma. 2002. p. 42.

${ }^{35}$ M. Syamsudin (Editor: M. Koesnoe, Heddy Shri Ahimsa Putra dkk), Ilmu Hukum Profetik (Gagasan Awal, Landasan Kefilsafatan dan Kemungkinan Pengembangannya di Era Postmoderen), Yogyakarta: Pusat Study Hukum FH-UII, Loc.Cit. 2013. p. 105 
Based on this assumption, the researcher cites the concepts contained in the Main Scientific Pattern (Pola Ilmiah Pokok/PIP) of the Faculty of Law UII concerning the essence of law as follows: ${ }^{36}$

"The essence of the law is the will and the highest will whose ultimate truth is the will of Allah The Almighty, which is destined for mankind, to attain a noble degree as God's representative on earth (Q.S. II: 30). Therefore, the law is a means and medium for human beings on the basis of their faith to obtain His grace (Q.S. II: 147; III: 360; XVIII: 29; V: 59). In the relation between human beings, human beings, and ecosystems, God's law must be ethics for man-made law. Man-made law is a consistent continuation of God's law (Q.S. V: 44 and 45; IV: 59). Thus, the upright and the existence of man-made law may wreak havoc on humans and their ecosystems if not based on God's will (Q.S. XIII: 41) ".

In the above excerpt, it can be determined that the main basis of Legal Prophetic is the teachings of Islam contained in the Qur'an, Hadith, and Sunnah of the Prophet must be understood and comprehended well in advance as the foundation for the whole building of Prophetic Sciences. Especially understanding of the relevant elements will be very helpful in establishing Legal Prophetic. In this context, it requires knowledge, adequate and correct understanding of the Qur'an, Hadith, and Sunnah of the Prophet and proper knowledge and understanding of the Philosophy of Science and Philosophy of Law.

Prophetic science is based on the Qur'an and Hadith and is then described in the pillars (Faith and Islam) ${ }^{37}$ which have a basis of knowledge (senses, the ability to structure and

${ }^{36}$ Panduan Akademik, Pola Ilmiah Pokok (PIP) Fakultas Hukum UII, Yogyakart: Universitas Islam Indonesia, 1997/1998. pp. 21-24, In M. Syamsudin (Penyunting: M. Koesnoe, Heddy Shri Ahimsa Putra dkk), Ilmu Hukum Profetik (Gagasan Awal, Landasan Kefilsafatan dan Kemungkinan Pengembangannya di Era Postmoderen), Yogyakarta: Pusat Study Hukum FH-UII, 2013. Op.Cit. pp. 104-106.

37 "... the pillars of faith, namely the things that must be believed by a Muslim, namely (1) Belief in Allah, (2) Belief in the Angels, (3) Belief in the God's revealed books, (4) Belief in the Prophets and the Messengers of Allah, (5) Belief in the Day of the Judgment, and (6) Belief in Al-Qadr (Divine Predestination). These pillars of faith are in the field of beliefs about religion. To be relevant to prophetic (social) science, the Pillars of Faith need to be transformed in such a way that is appropriate to the context, namely the scientific context. And if you think further, "faith" is nothing but "relation". Faith in God means "building a relationship with God", and the most appropriate relationship is "devotion", "to whom I serve." In the context of prophetic science, God here is transformed into Knowledge, because God is the Source of Knowledge. Faith in God in the context of prophetic science is faith in knowledge itself. Faith in the Angels means "building relationships with the angels", and the right relationship is "friendship" because angels are friends or friends of believers. Belief in the God's revealed Books is to establish a relationship with the God's revealed books, and the right relation is "reading" because the book is something that is read. Belief in the Prophets is to build relationships with the Prophets, and the right relationship is "college and friendship". That is, a Muslim perceives the Prophets as teachers who give knowledge, as well as friends, as the relationship that occurs between the Prophet Muhammad PBUH. with His companions. Belief in the Day of the Judgment is building relationships with the Day of the 
symbolize, language, revelation, sunnah of the Prophet PBUH). Then it descends into basic more concrete assumptions/basic principles. Basic assumptions about material objects (origin, causes, nature), basic assumptions about the phenomenon under study (origin, causes, nature), basic assumptions about science (objective, nature, types), basic assumptions about social/cultural/natural/prophetic sciences (objective, nature, types), as well as basic assumptions about prophetic (objective, nature, types).

The four complete instruments given to human beings to "understand" (al-Ilmu, AlHikmah, Syahwat, and Al-Kalimah) are potentials with the power to develop in accordance with the efforts of each individual. However, there is a fifth tool (which is only given to the human being chosen by God and is special, namely al-Huda (guidance). This potential serves to find out the Divine pattern in relation to the "righteous path" of the purpose of the creation of the universe, and all of His creatures from the beginning of creation to the end, the potential for this "guidance" will only be given by Allah to the faithful and pious individual. ${ }^{38}$

\section{CONCLUSION}

The epistemological assumptions of the school of thought of Legal Positivism have categories including; (a) there is constitutive cognition, (b) norm is an independent and autonomous meaningful object of cognition, and (c) reconstructed legal norms are formed from relations between material facts that are non-causal and non-metaphysical (imputation). On the other hand, the main basis of Legal Prophetic is the teachings of Islam contained in the Qur'an, the Hadith, and the Sunnah of the Prophet that must be understood and comprehended well in advance as a foundation for the entire Prophetic Sciences. Especially understanding the

\footnotetext{
Judgment, and the right relationship is "prevention" because Day of the Judgment in this context can be interpreted as "destruction". Belief in Al-Qadr is building relationships with Destiny, and the right relationship is "acceptance". This means that Muslims view destiny as something that cannot be avoided, and therefore the right relation is to accept. Destiny in the scientific context can be interpreted as "natural law".

Pillars of Faith, in the context of prophetic (social) science the pillars of Islam certainly need to be transformed, and what is transformed here is not only beliefs, but also rituals are beliefs, principles followed, adhered to, and things that must be carried out by every Muslim. There are five pillars of Islam: (a) the testimony of faith (shahada); (b) prayer; (c) fasting; (d) zakat (almsgiving); and (e) pilgrimage (hajj). These pillars of Islam need to be transformed into the practice of daily scientific life, just as the pillars of Islam must also be realized in everyday life. This is where the pillars of Islam will become manifestations of the ethos that exists in prophetic (social) science, and the basis of the practice of scientific life is the transformation of the first pillars of faith, namely service, because basically the pillars of Islam are manifestations in the form of actions or practices, from the faith. In Heddy Ahimsa-Putra Shri. Paradigma Profetik: Mungkinkah? Perlukah?, Paper delivered in "Sarasehan Profetik 2011", presented by Graduates School of UGM, Yogyakarta, on February 10 $0^{\text {th }}$, 2011. pp. 2931

${ }^{38}$ Heddy Ahimsa-Putra Shri. Paradigma Profetik: Mungkinkah? Perlukah?, Paper delivered in "Sarasehan Profetik 2011”, Presented by Graduates School of UGM, Yogyakarta, February 10 ${ }^{\text {th }}$, 2011. Ibid. Loc.Cit. p. 31
} 
relevant elements will be very helpful in creating Legal Prophetic. In this context, it requires knowledge and adequate and correct understanding of the Qur'an, Hadith, and Sunnah of the Prophet and proper knowledge and understanding of the Philosophy of Science and Philosophy of Law.

Prophetic science is based on the Qur'an and Hadith and is then described in the pillars (Faith and Islam), which have a basis of knowledge (senses, the ability to structure and symbolize, language, revelation, sunnah of the Prophet PBUH). Then it descends into more concrete basic assumptions/basic principles. Basic assumptions about material objects (origin, causes, nature), basic assumptions about the phenomenon under study (origin, causes, nature), basic assumptions about science (objective, nature, types), assumptions basic about social/cultural/natural/prophetic sciences (objective, nature, types) as well as basic assumptions about prophetic (objective, nature, types). 


\section{REFERENCES}

\section{Books}

Anshori Abdul Ghofur, Filsafat Hukum, Sejarah, Aliran dan Pemaknaan, Yogyakarta: Gajah Mada University Press, 2006;

Dimyati Khudzaifah, SH., M. Hum. TEORISASI HUKUM: Studi Tentang Perkembangan Pemikiran Hukum Di Indinesi,. Surakarta :Muhammadiyah Universitas Press, 2004;

Hardiman, F. Budi, Filsafat Modern Dari Machiavelli Sampai Nietszche, .Jakarta : PT. Gramedia Pustaka Utama. 2007;

Icham Moch Nur, Meretas Kesarjaan Kritis Al-Quran: Teori Hermeneutika Nas Abu Zayd, Teraju, Jakarta, 2003;

Kuntowijoyo, Islam Sebagai Ilmu: Epistemologi, Metodologi dan Etika, Jakarta: Teraju PT. Mizan Publika, 2004; , Paradigma Islam Interpretasi Untuk Aksi, Bandung: Mizan, 1998; , Identitas Politik Umat Islam, Bandung: Mizan, 1997;

Rahardjo Satjipto. Sosiologi Hukum Perkembangan Metode dan Pilihan Masalah. Surakarta: Muhammadiyah University Press, 2002;

Shidarta, Bandung, Karakteristik Penalaran Hukum Dalam Konteks Keindonesiaan, Bandung: CV. Utomo, 2006;

Syamsudin, M. (Penyunting: M. Koesnoe, Heddy Shri Ahimsa Putra dkk). Ilmu Hukum Profetik (Gagasan Awal, Landasan Kefilsafatan dan Kemungkinan Pengembangannya di Era Postmoderen), Yogyakarta: Pusat Study Hukum FH-UII, 2013.

Webster's New Twentieth Century Dictionary, 2nd edition, United State of America: William Collin Publishers, Inc, 1979;

Wignjosoebroto, Soetandyo. Hukum Paradigma, Metode dan Dinamika Masalahnya, Jakarta: Huma. 2002.

\section{Researches and Papers}

Ahimsa-Putra Heddy Shri, Paradigma dan Revolusi Ilmu dalam Antropologi Budaya, Sketsa Beberapa Episode, Speech in Professor Inauguration in Faculty of Cultural Science Gadjah Mada University, Delivered in Open Meeting of Professor Gajah Mada University, Yogyakarta, on November10th, 2008. , Paradigma Profetik: Mungkinkah? Perlukah?, Paper delivered in "Sarasehan Profetik 2011", presented by Graduates School of UGM, in Yogyakarta, February 10th, 2011.

Chariri Anis, "Landasan Filsafat dan Metode Penelitian Kualitatif", Paper delivered in Workshop of Quantitative and Qualitative Research Methodology, Laboratory of Accounting Development (Laboratorium Pengembangan Akuntansi/LPA), Faculty of Economy Diponegoro University, Semarang, July 31st-August 1st, 2009.

Rochman Saepul, Thesis, Paradigma Profetik Dalam Ilmu Hukum (Kritik Terhadap AsumsiAsumsi Dasar Ilmu Hukum Non-sistematik), Surakarta: Faculty of Law Universitas Muhammadiyah Surakarta, November 2014;

Wardiono, Kelik. "Paradigma Profetik (Pembahasan Basis Epistemiligi Ilmu Hukum di Indonesia)", Paper delivered in Seminar of Dissertation Research Result Doctoral 
Program Surakarta: Law Science faculty of Law Graduate School of Universitas Muhammadiyah Surakarta, on September 13 $3^{\text {th }}, 2014$.

\section{Internet}

Azzahra Kaila, Aliran Filsafat Positivisme, In http://kaylaazzrt.blogspot.com/2013/01/tugasmakalah-konsep-pikir-aliran_1401.html, accessed on June 20 ${ }^{\text {th }}, 2020,23.40$

Friedmann, W. 1990. Teori dan Filsafat Hukum. Jakarta: Rajawali, p. 257 In Franssisca Yuliana, Filosofi Ilmu Hukum in http://siscayulai.blogspot.com/2010/09/filosofiilmu-hukum.html, accessed on May 23 ${ }^{\text {rd }}, 2020,1.35$

Purwaningsih Indriyani, "Perspektif Positivisme \& Post-Positivisme", http://catatananakfikom.blogspot.com/2012/03/perspektif-positivisme-post-positivisme.html, accessed on June $20^{\text {th }}, 23.40$

Reisskop Victor and Isaac Newton. In Wikipedia.org, Correspondence Theory of Truth in http://perilakuorganisasi.com/teori-kebenaran-ilmiah.html accessed on May $21^{\text {st }}$, 2020, 23.40

Wikipedia.org, Correspondence Theory of Truth In http://perilakuorganisasi.com/teorikebenaran-ilmiah.html, accessed on May 26 ${ }^{\text {th }}, 2020,23.40$;

Yuliana Franssisca, Filosofi Ilmu Hukum in http://siscayulai.blogspot.com/2010/09/filosofiilmu-hukum.html, accessed on May 23 ${ }^{\text {rd }}$, 2020, 1.35;

Zainal Asikin, Mazhab Positivisme Hukum, http://asikinzainal.blogspot.com/2012/10/mashabpositifisme-hukum.html, accessed on May 27 th $2020,23.25$. 